\title{
3 Promoting Asian basket currency bonds
}

\author{
Takatoshi lto
}

With many Asian countries experiencing robust growth since 1999, the East Asian currency crisis of 1997-98 seems to be just a distant memory. However, just when you think you are in safe waters, perils may sneak up on you again. Some countries, such as Thailand and Indonesia, are experiencing strong capital inflows and the currencies may be appreciating beyond levels that might be justified by the fundamentals.

Many of the recommendations that were identified after the crisis have not been implemented. Three of these recommendations are examined in this chapter.

- Reduce vulnerability to avoid the double mismatch problem, namely currency and maturity mismatches of borrowers in emerging market companies-to borrow short in US dollars and lend long in local currency is dangerous.

- Avoid over-reliance on the banking sector, since a twin crisis (a simultaneous currency and banking crisis) is damaging to the economy.

- Avoid the dollar peg, both from the viewpoint of maintaining price competitiveness of imports and of discouraging too many short-term capital inflows.

Reliance on the banking system can be reduced by promotion of bond financing. If the government and corporations can issue bonds for longterm projects then they can reduce borrowing from banks. Banks also benefit from avoiding maturity mismatch. One of the problems is that bondmarkets in emerging market economies have not been developed in terms of market institutions. The bondmarket in an emerging market may benefit from an effort to broaden the market to the region, since inviting foreign investors 
will deepen the market. However, in order to attract investors into the bondmarket, transparency may have to be enhanced. Therefore, it is desirable to establish a region-wide bondmarket.

Asian bonds have been proposed, most prominently by Prime Minister Thaksin of Thailand. The Asian bond has become a focal point for regional financial cooperation after the Chiang Mai Initiative.

\section{Asian bonds}

Asian bonds are issued by Asian institutions (governments, corporations, and financial institutions), denominated in an Asian currency, rated by Asian rating agencies, and sold, traded, cleared and settled at an Asian financial centre (Tokyo, Singapore or Hong Kong SAR). Investors are expected to be mainly regional (Japan, Singapore and Hong Kong SAR in particular), but other investors are welcome. The components of an Asian bond are the issuer, the currency denomination and the location of a secondary market. Even if only two of the three conditions are met, they may still be called Asian bonds. Rating agencies would assist in creating a market, and Asian investors are naturally more attracted to Asian bonds than are outside investors.

In order to solve the double mismatch problem (discussed in earlier chapters), it is essential that Asian bonds be issued in a local currency, or a basket of local currencies. By issuing bonds in the local currency, governments or corporations are freed from the possibility of an acute dollar liquidity shortage, unless maturities are bunched in particular months. Major trading centres should be regional so that settlement and clearance transactions can be completed in real time. This can be achieved if regional central banks extend the real time gross settlement facility to financial centres, and settlement and clearance facilities are developed in regional financial centres.

Investors are known to have a 'home bias', that is, the investor's portfolio-especially in the case of equities-is heavily biased toward domestic securities. Home bias may exist for a number of reasons, including avoidance of currency risk, familiarity with local products and the existence of multinationals. Since home bias exists, there may also be 'regional bias', in that investors may be attracted toward securities issued by countries in the region, second to domestic securities. The currencies in the region are more highly correlated than other currencies, and familiarity with regional companies and currencies is high, that is why major investors into Asian bonds are Asian investors. 


\section{Objectives of promoting Asian bonds}

Asian bonds provide financial instruments to avoid double mismatch. Second, they develop a market and a channel of converting regional saving to regional investment, creating a bridge between investors and corporate/ government borrowers. As the region is expected to maintain high economic growth, good investment opportunities exist. The region is also known to be populated with strong savers. Third, spreading risk from the banking sector to other financial institutions will lessen the risk of another severe financial crisis; this strategy avoids a twin crisis.

Let us examine two questions. Who would be the issuers and the borrowers if a well-functioning bondmarket was established and what would be the benefits for them? Borrowers will benefit from issuing bonds in local currencies and can match revenues in local currencies by borrowing in local currencies. Corporations exporting within the region also can issue liabilities in the destination currencies of their exports.

By issuing bonds instead of borrowing from banks, corporations can diversify risk. Even when banks fall into financial difficulties, corporations have alternative funding sources. Risk will be diversified. Better-funded corporations can borrow, even at low rates. Capital costs will be thus lowered.

Investors in the region can also benefit from having alternative investment opportunities. They would welcome high quality Asian-currency denominated bonds and would offer a reasonable risk-yield trade-off.

One of the puzzles in financial economics is home bias-investors hold domestic securities (equities and bonds) in a far higher proportion than theoretically warranted. Home bias can be rooted in familiarity and aversion to currency risk. If these are the reasons for home bias, there could be 'regional bias'. Japanese investors could may find Korean and Thailand firms more familiar than Latin American and Central European firms.

After the East Asian currency crisis, most Asian currencies are floating. The correlation of an Asian currency with the yen has increased after the crisis, although the correlation coefficient seems to fluctuate, the currency risk of Asian bonds (denominated in Asian currencies) for Asian investors must be less than that of bonds denominated in US dollars or the euro.

Despite the benefits of the Asian bondmarket, there are obstacles to quick establishment. Disclosure and transparency of Asian securities and borrowers are not as good as the United States and European counterparts. The legal and market infrastructure of the bondmarket is also weak. 


\section{The Asian Bond Fund}

In June 2003, the Executives' Meeting of East Asia-Pacific Central Banks (whose members consist of central banks of Australia, China, Hong Kong SAR, Indonesia, Japan, Korea, Malaysia, New Zealand, the Philippines, Singapore and Thailand) announced that they would contribute US $\$ 1$ billion to the Asian Bond Fund, managed by the Bank for International Settlements, in order to invest in dollar-denominated, sovereign and quasi-sovereign bonds issued by Asian issuers. ${ }^{1}$ The central banks will set aside a portion of their foreign reserves (estimated to be more than US\$1 trillion) to invest in the Fund. Eligible securities are those issued by governments and quasigovernments.

Will the Asian Bond Fund help the creation of the Asian bondmarket? The Asian Bond Fund is, at best, a good step toward an eventual development of the Asian bondmarket. However, this proposal does not exactly fit what was envisioned as Asian bonds. First, the use of the US dollar, presumed in the current version of the Asian Bond Fund, does not contribute to the financial and monetary stability of the region. Thus establishing and enlarging the Asian Bond Fund will not avoid the double mismatch problem. Second, under the current version of the Asian Bond Fund, monetary authorities buy and hold Asian bonds as foreign exchange, so a secondary market of Asian bonds will not develop. Third, central banks contributed to the Asian Bond Fund, but foreign reserves are strictly regulated as eligible securities. That is why investment is limited to sovereign and quasi-sovereign bonds. Due to the regulation, the market size of bonds in which the Asian Bond Fund can invest will be limited. However, promoting corporate bonds and asset-backed securities is very important for the region.

A new direction is needed. One idea is to broaden the asset class of the Asian Bond Fund. Suppose that the central banks decide to establish Asian Bond Fund $\mathrm{I}$, able to invest in local-currency denominated bonds. This solves the first problem-helping countries to avoid the double mismatch problem. Even if this happens, the (quasi) sovereign bond condition is difficult to remove, so long as the central banks desire the funds to be counted toward foreign reserves. Lower credit-rated securities, such as corporate bonds or asset-backed securities would not qualify for foreign reserves.

Another idea is to promote issues, trade and investment in Asian bonds by private sector participants. Government bonds denominated in local currency should be issued in order to provide a benchmark for private issues. A main objective would be to nurture corporate bonds and asset-backed securities issues in local currency, being traded regionally. 


\section{Current role of bonds in Asia}

Let us review how bonds are issued and traded in Asia today (see also Rhee 2003). Table 3.1 shows the size of bank loans, stockmarket capitalisation, government bonds and corporate bonds of Asian countries, with Japan and United States as reference, for 1997 and 2002. In all countries, except the Philippines and Indonesia (in 2002), bank loans are much bigger than government bonds. Since many Asian countries adopted a balanced budget policy, government bond issues before the currency crisis were very limited. Only after the currency crisis did government bond issues increase sharply to finance budget deficits. Government bonds in Indonesia increased sharply due to recapitalisation of banks by government bonds. After the currency crisis of 1997-98, banks in Indonesia suffered massive losses and most banks became insolvent. The government injected large amounts of capital into many banks in the form of government bonds. In 2002, about 90 per cent of government bonds were held by commercial banks for the purpose of recapitalisation. These bonds could be sold for cash, and there is a tendency for bonds to have been made into mutual funds and sold to investors. This may help to establish the government bondmarket.

Many Asian countries increased the amount of government bond issues after the currency crisis of 1997-98. For example, Indonesia had not used government bonds before the crisis, as its regular budget was balanced, although its development budget was financed by borrowing from abroad. However, bond issues increased sharply after the crisis, especially because of the need to finance deficits caused by bank recapitalisation. Bonds were issued specifically for that purpose, thus they were called recapitalisation bonds. Some of the recapitalisation bonds are not allowed to be sold, but others can be sold to investors. In 2002 and 2003, some of recapitalisation bonds were sold to mutual funds. The frequency and total size of the secondary market transactions are still very low (Table 3.2 and Table 3.3 ).

The size of corporate bonds is very small in all countries except Singapore, where the size is comparable to the United States. In the United States, corporate bonds are bigger than bank loans, stockmarket and capitalisation exceeds GDP in Malaysia, Singapore and Hong Kong SAR. The capitalisation ratio of these three economies exceeds that of the United States. The ratio of government bonds to GDP increased in all East Asian countries from 1997 to 2002, while the ratio declined in the United States. The ratio of corporate bonds to GDP also increased in all East Asian countries, except in Indonesia.

There was a sharp increase in government bond issues from 1997 to 1999 in several countries, including Indonesia, Thailand and Korea in the wake of 
Table 3.1 Size of capital markets of East Asian countries and the United States, 1997 and 2002 (US\$ billion)

\begin{tabular}{|c|c|c|c|c|c|c|c|c|}
\hline & \multicolumn{2}{|c|}{$\begin{array}{l}\text { Outstanding balance } \\
\text { of bank loans }\end{array}$} & \multicolumn{2}{|c|}{$\begin{array}{l}\text { Total market } \\
\text { capitalisation }\end{array}$} & \multicolumn{2}{|c|}{$\begin{array}{l}\text { Outstanding balance } \\
\text { of government bonds }\end{array}$} & \multicolumn{2}{|c|}{$\begin{array}{l}\text { Outstanding balance } \\
\text { of corporate bonds }\end{array}$} \\
\hline & 1997 & 2002 & 1997 & 2002 & 1997 & 2002 & 1997 & 2002 \\
\hline Indonesia & 60 & 23 & 25 & 17 & - & 40 & 3 & 1 \\
\hline Malaysia & 98 & 94 & 133 & 133 & 24 & 30 & 17 & 29 \\
\hline Philippines & 60 & 37 & 52 & 52 & 61 & 79 & 5 &.. \\
\hline Thailand & 121 & 81 & 23 & 37 & 5 & 21 & 3 & 5 \\
\hline Korea & 44 & 79 & 16 & 43 & 6 & 17 & 20 & 30 \\
\hline Taiwan & 112 & 119 & 116 & 93 & 12 & 23 & 4 & 14 \\
\hline Singapore & 101 & 103 & 233 & 185 & 16 & 37 & 22 & 57 \\
\hline Hong Kong SAR & 152 & 144 & 238 & 284 & 8 & 9 & 19 & 33 \\
\hline China & 106 & 169 & 24 & 37 & 7 & 19 & 1 & 1 \\
\hline Japan & 101 & 85 & 54 & 50 & 49 & 99 & 7 & 12 \\
\hline United States & 37 & 40 & 159 & 112 & 45 & 35 & 43 & 59 \\
\hline
\end{tabular}

Source: Yamagami, H., 2003. 'Asian bond market -a scheme for ABS issuers', Japanese Bankers Association, Kin-yu, November:2-15. 
Table 3.2 Government bonds ownership in Indonesia, 2000-2002 (million rupiah)

\begin{tabular}{|c|c|c|c|c|}
\hline & 2000 & 2001 & 2002 & Per cent \\
\hline Ministry of Finance & - & 877,545 & 872,545 & 0.2 \\
\hline Recap banks & $390,143,372$ & $356,271,301$ & $334,573,956$ & 79.8 \\
\hline State banks & $250,184,352$ & $235,422,965$ & $228,176,234$ & 54.5 \\
\hline Private banks & $32,649,312$ & $29,772,917$ & $22,646,557$ & 5.4 \\
\hline Taken-over banks & $106,079,258$ & $89,844,969$ & $82,538,678$ & 19.7 \\
\hline Regional development banks & $1,230,450$ & $1,230,450$ & $1,212,487$ & 0.3 \\
\hline Non-recap banks & $6,954,361$ & $24,772,569$ & $13,829,234$ & 3.3 \\
\hline Sub-registry & $1,823,861$ & $13,022,018$ & $44,782,147$ & 10.7 \\
\hline Insurance & $1,042,611$ & $3,758,511$ & $6,512,792$ & 1.6 \\
\hline Mutual fund & 16,500 & $2,025,284$ & $35,719,912$ & 8.5 \\
\hline Pension fund & 5,750 & $160,750,6$ & 360,411 & 0.1 \\
\hline IBRA & 755,000 & $6,661,328$ & $1,908,124$ & 0.5 \\
\hline Corporate & 2,000 & 109,177 & 71,880 & - \\
\hline Securities & - & 301,968 & 133,603 & - \\
\hline Foundation & - & 3,000 & - & - \\
\hline Individual & - & 2,000 & - & - \\
\hline Others & - & $\cdot$ & 75,425 & $=$ \\
\hline Hedge bonds (non-tradable) & $32,880,567$ & $40,359,512$ & $25,298,505$ & 6.0 \\
\hline Recapitalisation-state banks & $32,880,567$ & $28,477,503$ & $18,173,654$ & 4.3 \\
\hline Recapitalisation-private banks & - & $11,882,009$ & $7,124,850$ & 1.7 \\
\hline Total & $431,802,161$ & $435,302,945$ & $419,356,387$ & 100 \\
\hline
\end{tabular}


the currency crisis. Government bonds in Taiwan, Korea, Indonesia and Thailand increased substantially from 2001 to 2002 (Table 3.4).

From 1997 to 2002, there was a trend towards corporate bonds in all countries except Indonesia and the Philippines. Outstanding amounts more than doubled in Malaysia, Taiwan and Singapore (Table 3.5).

Those economies most severely hit by the currency crisis, such as Indonesia, increased their proportion of government bonds but did not increase corporate bonds. Countries that were hit by the currency-banking crisis, such as Thailand, Malaysia, Korea and Singapore, recovered quickly and developed corporate bondmarkets.

In both types of countries bank loans declined, since the currency crisis was accompanied by a banking crisis. A sharp decline shows the danger of over-reliance on bank loans. The impact on the banking sector would have spread to the entire economy quickly, suggesting that the economy would be better off having alternative financing channels, such as corporate bonds.

Table 3.3 Bond transactions in secondary markets in Indonesia, $2000-2003$

\begin{tabular}{|c|c|c|c|c|}
\hline \multicolumn{3}{|c|}{ Corporate bonds } & \multicolumn{2}{|c|}{ Government bonds } \\
\hline & $\begin{array}{c}\text { Volume } \\
\text { billion rupiah) }\end{array}$ & Frequency & $\begin{array}{c}\text { Volume } \\
\text { (billion rupiah) }\end{array}$ & Frequency \\
\hline 2000 & $8,791.74$ & 2,495 & $27,905.83$ & 161 \\
\hline 2001 & $1,048.42$ & 385 & $66,172.11$ & 1167 \\
\hline \multicolumn{5}{|l|}{2002} \\
\hline January & 144.90 & 61 & $6,626.96$ & 214 \\
\hline February & 152.00 & 46 & $10,562.98$ & 297 \\
\hline March & 61.00 & 22 & $8,448.65$ & 284 \\
\hline April & 630.77 & 90 & $3,721.35$ & 187 \\
\hline May & 366.12 & 115 & $10,460.72$ & 300 \\
\hline June & 510.69 & 204 & $9,035.66$ & 273 \\
\hline July & 633.75 & 266 & $14,186.15$ & 396 \\
\hline August & 535.00 & 220 & $17,302.75$ & 487 \\
\hline September & 790.51 & 311 & $16,688.59$ & 468 \\
\hline October 1 & $1,330.63$ & 409 & $12,264.51$ & 431 \\
\hline November & 381.22 & 173 & $10,563.25$ & 439 \\
\hline December & 381.22 & 173 & $14,186.15$ & 396 \\
\hline \multicolumn{5}{|l|}{2003} \\
\hline January & 416.77 & 121 & $17,597.60$ & 581 \\
\hline
\end{tabular}

Source: Subiyantoro, H., and Ginting, L.S., 2003. Indonesian government bonds market development, Paper presented at Asian Bond Symposium, Keio University, Japan, February. 
Table 3.4 Outstanding government bonds, East Asian economies and the United States, 1996-2002

\begin{tabular}{|c|c|c|c|c|c|c|c|}
\hline & 1996 & 1997 & 1998 & 1999 & 2000 & 2001 & 2002 \\
\hline Indonesia &. &.. & 12,461 & 71,993 & 68,793 & 63,468 & 72,785 \\
\hline Thailand & 705 & 291 & 11,227 & 15,676 & 15,229 & 15,980 & 25,836 \\
\hline Malaysia & 26,457 & 17,026 & 19,740 & 20,615 & 23,543 & 27,224 & 28,829 \\
\hline Philippines & 28,465 & 18,943 & 22,008 & 24,477 & 21,614 & 24,723 & .. \\
\hline Korea & 29,969 & 16,755 & 34,551 & 53,779 & 56,307 & 62,703 & 82,844 \\
\hline Taiwan & 36,085 & 31,742 & 32,344 & 39,624 & 44,708 & 53,096 & 63,722 \\
\hline Singapore & 14,645 & 13,065 & 17,242 & 21,188 & 24,973 & 28,974 & 33,429 \\
\hline Hong Kong SAR & 11,873 & 13,123 & 12,581 & 13,110 & 13,930 & 14,589 & 15,065 \\
\hline China & 52,559 & 66,534 & 93,803 & 127,327 & 157,296 & 188,696 & 233,168 \\
\hline Japan & $2,109,122$ & $1,985,283$ & $2,554,058$ & $3,245,291$ & $3,198,909$ & $3,309,519$ & $4,142,314$ \\
\hline United States & $3,755,076$ & $3,778,273$ & $3,723,674$ & $3,652,683$ & $3,357,764$ & $3,352,741$ & $3,609,754$ \\
\hline
\end{tabular}

Source: Yamagami, H., 2003. 'Asian bond market -a scheme for ABS issuers', Japanese Bankers Association, Kin-yu, November:2-15. 
Table 3.5 Outstanding corporate bonds, East Asian economies and the United States, 1996-2002

\begin{tabular}{lrrrrrrr}
\hline & 1996 & 1997 & 1998 & 1999 & 2000 & 2001 & 2002 \\
Indonesia & 4,153 & 3,356 & 1,807 & 2,245 & 2,333 & 1,994 & 2,396 \\
Thailand & 5,083 & 2,807 & 3,430 & 4,787 & 4,839 & 5,692 & 6,489 \\
Malaysia & 13,257 & 11,972 & 12,299 & 20,693 & 26,446 & 30,967 & 27,368 \\
Philippines & 22,892 & 3,006 & 3,075 &.. &.. &.. &.. \\
Korea & 90,033 & 53,160 & 101,895 & 105,115 & 105,692 & 117,244 & 151,745 \\
Taiwan & 9,110 & 9,903 & 19,380 & 21,913 & 24,217 & 28,890 & 39,839 \\
Singapore & 18,574 & 18,502 & 19,271 & 25,810 & 28,588 & 43,652 & 51,368 \\
Hong Kong SAR & 25,278 & 32,668 & 38,888 & 43,993 & 46,626 & 48,745 & 53,204 \\
China & 7,203 & 6,293 & 8,177 & 9,404 & 10,409 & 12,186 &.. \\
Japan & 265,921 & 286,876 & 393,561 & 488,315 & 470,138 & 437,140 & 499,794 \\
United States & $3,205,100$ & $3,594,500$ & $4,187,400$ & $4,626,400$ & $5,022,900$ & $5,692,300$ & $6,207,800$ \\
\hline
\end{tabular}

Source: Yamagami, H., 2003. 'Asian bond market -a scheme for ABS issuers', Japanese Bankers Association, Kin-yu, November:2-15. 
Next, let us consider the question of bonds turnover. Even when outstanding balances of government and corporate bonds increase, the market is not functioning if bonds are held by institutions and not traded. Active trading took place in the secondary market, although most of the trading is over-the-counter rather than at the Korean Stock Exchange (Table 3.6a). Turnover ratios of Indonesia are extremely low, due to the recapitalisation bond phenomenon described above (Table 3.6b). The turnover ratio in Malaysia has been steadily increasing (Table 3.6c).

The data in these tables point to the challenges and potential of the Asian bondmarket. Government bonds may have to be regularly issued, whether funding needs are there or not, so that the market will deepen. The market infrastructure of corporate bonds has to be examined so that alternative funding sources for corporations will be available.

\section{Proposal for an Asian Bond Corporation}

In order to achieve the objectives of the Asian Bond Markets Initiative, several steps need to be taken. There are two different kinds of problems: for issuers, any obstacles for potential issuers to issue local-currency denominated bonds should be identified and removed; for investors, if they feel that localcurrency denominated bonds issued by Asian issuers are too risky, both in currency and in credit, then those concerns must be examined and allayed. Investors may not correctly interpret information on the quality of issuers if information about the company and credit rating (that is, an aggregate quantification of information) is not readily available and credible to investors. Informational asymmetry would destroy the regional market.

One way to promote Asian bonds is to establish an organisation that can bridge issuers and investors from different economies. Issuers would prefer to issue bonds in local currency, for example the Thai baht, while investors would like to receive returns and principal in their local currency, for example, the yen. Similarly, issuers in different countries would like to issue bonds in local currencies. If the currency risk can be mitigated, investors may be more attracted to the bonds. One way to reduce volatility, or risk, in returns to the yen is to construct a basket of bonds in different currency denominations. Each currency may carry risks, but when they are grouped into a basket, the aggregate risk may be less.

This chapter proposes the establishment of a corporation (an offshore entity) to purchase local currency bonds and transform these into a basket currency bond. The entity may be called the Asian Bond Corporation, and will issue $A B C$ bonds that reflect the value of underlying assets. The basket 
Table 3.6a Korea's bond turnover ratio, 1995-2002

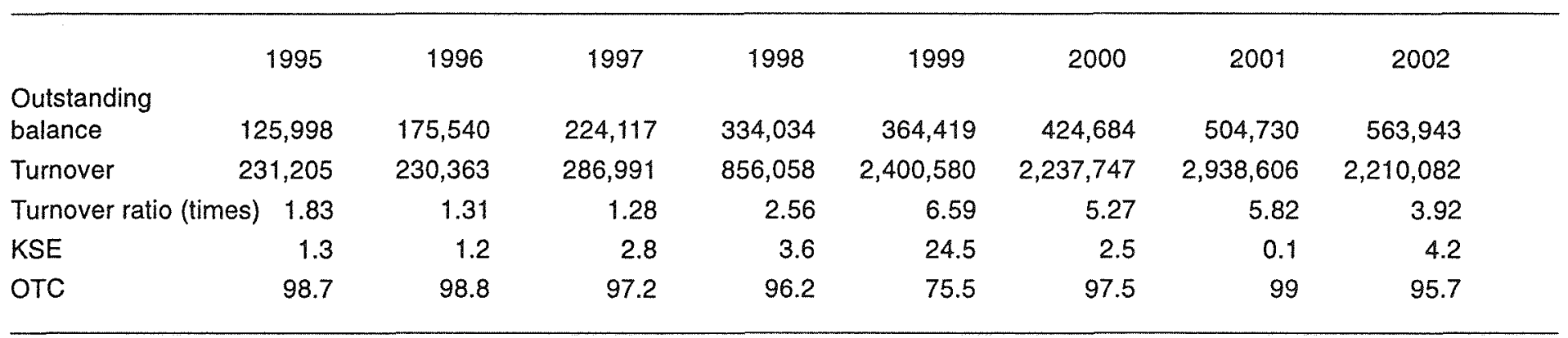

Source: Fukuchi, A., 2003. 'Trend of Asian bond market', Tokyo-Mitsubishi Review, October:1-8.

Table 3.6b Malaysia's bond turnover ratio, 1995-2002

\begin{tabular}{lrrrrrrrr}
\hline & 1995 & 1996 & 1997 & 1998 & 1999 & 2000 & 2001 & 2002 \\
Outstanding & & & & & & & & \\
balance & 3,846 & 25,373 & 12,367 & 33,085 & 63,838 & 88,625 & 219,942 & 244,135 \\
Turnover & 64,719 & 66,910 & 66,262 & 75,012 & 78,336 & 89,050 & 103,450 & 109,550 \\
Turnover ratio (times) & 0.06 & 0.38 & 0.19 & 0.44 & 0.81 & 1.00 & 2.13 & 2.23 \\
\hline
\end{tabular}

Source: Fukuchi, A., 2003. 'Trend of Asian bond market', Tokyo-Mitsubishi Review, October:1-8. 
Table 3.6c Indonesia's bond turnover ratio, 1998-2002

\begin{tabular}{lrrrrr}
\hline & 1998 & 1999 & 2000 & 2001 & 2002 \\
$\begin{array}{lcrrr}\text { Outstanding } \\
\text { balance }\end{array}$ & 100,000 & 496,600 & 653,900 & 695,000 & 650,700 \\
$\begin{array}{l}\text { Turnover } \\
\text { Turnover ratio (times) }\end{array}$ & & & 64,546 & 130,787 \\
& & 0.10 & 0.20 & \\
\hline
\end{tabular}

Source: Fukuchi, A., 2003. 'Trend of Asian bond market', Tokyo-Mitsubishi Review, October:1-8.

of bonds by the Asian Bond Corporation would include bonds with the same maturity, so that maturity mismatch would not occur (Chaipravat 2003, Ito 2003a, Oh, Park and Yang 2003).

Since the $A B C$ basket bond is fully backed by the assets of the Asian Bond Corporation, the basket bond has a property of a weighted average of underlying bonds, in terms of currency fluctuation, coupons, and default risk. If the underlying bonds were sovereign, the $\mathrm{ABC}$ bond would perform like a sovereign. Credit risk would be minimised unless the issuing government has low credit rating. If the underlying bonds are corporate bonds, basket bonds would carry default risk and premium, similar to the weighted average of risk and premium of the underlying bonds. The ABC sovereign bonds would provide a benchmark for corporate bonds.

Let us consider concrete steps to implement this proposal. The fiscal authorities of Japan, Korea and Thailand, and any other willing Asian countries, should jointly establish the Asian Bond Corporation in offshore market (Tokyo, Hong Kong SAR or Singapore). The Corporation will purchase sovereign bonds (later, corporate bonds and asset-backed securities) of the participating countries, issued in the respective local market and denominated in the yen, won, baht and other currencies. The Asian Bond Corporation's asset side is composed of a basket of bonds in different currency denominations and different coupon rates. The $A B C$ bond, on the liability side of the Asian Bond Corporation, is backed by the market value of the bonds on the asset side. Hence, pricing of $\mathrm{ABC}$ bonds in the secondary market should reflect the value of the underlying assets.

For example, we recommend that the Asian Bond Corporation initially purchase Japanese, Korean and Thai government bonds with value-weights of 50-30-20, respectively. Then the pricing of the $A B C$ bond reflects both the exchange rate fluctuations of the yen, the won and the baht, as well as the interest rate movements in the three countries of origin. With respect to 
currency risk, the $\mathrm{ABC}$ bonds show a feature of a basket currency, namely a weighted average of the three currencies. The coupon interest rate of the $\mathrm{ABC}$ bond will be a weighted average of the underlying bonds.

Many investors will find $A B C$ bonds attractive. Investors are willing to take some currency and credit risk to receive returns, but risks have to be transparent, fair and diversified. (Japanese investors currently receive only 0.8 per cent yield from holding Japanese bonds, but some of them are eager to purchase Australian dollar-denominated bonds yielding 5 per cent, reflecting currency and credit risk. They may be attracted to an $\mathrm{ABC}$ bond yielding 3 per cent, with lower currency risk.) The role of the Asian Bond Corporation is to bundle bonds from diverse sources, so that a reasonable trade-off point in the risk-return curve will be offered in a transparent manner. Regional investors who pursue higher returns without increasing too much of risk will regard bonds issued by the Asian Bond Corporation as just such financial instruments.

If credit risk of participating bonds makes $A B C$ bonds unattractive to risk averse-bond investors in the region, the partial guarantee may be offered by a credit enhancement agency. When corporate bonds and asset-backed securities are bundled into an $\mathrm{ABC}$ corporate bond, credit enhancement or separating into senior bonds and junior bonds may help widen the customer base. The role of asset-backed securities is emphasised in Oh et al. (2003), with several novel ways to separate junior and senior bonds. If currency risk, even as a weighted average, is not desirable for some home-biased investors, the Asian Bond Corporation, or its foreign exchange swap partners may offer swap into local currencies. Wong and Ho (this volume) review the role of private credit insurers in the United States.

The $A B C$ sovereign bonds will not assume any major risk, because the value and coupon payments of assets and liability matches all the time. It should behave like a currency board or a mutual fund. The Asian Bond Corporation helps create the Asian bond secondary market. The Corporation encourages the issues of bonds in the region. The $A B C$ sovereign bond should give the benchmark for corporate bonds and Asian Bond Corporation assetbacked securities bonds.

The Asian Bond Corporation proposal has several advantages over the Asian Bond Fund proposal. The Asian Bond Corporation promotes local currency bond issues, while the Asian Bond Fund in the current version invests in the dollar-denominated bonds only. The Asian Bond Corporation will bundle them as a basket-currency bond for investors.

In this proposal, $\mathrm{ABC}$ bonds promote the secondary market by issuing bonds, while Asian Bond Fund does not: the central banks in the Asian Bond 
Fund are buyer-investor, while the Asian Bond Corporation is an issuer as well as a buyer. $A B C$ bonds will have a secondary market in the country with investors. In this sense, the two proposals are quite complementary, while the Asian Bond Corporation is based on market participants and principles. The Asian Bond Corporation will have no limit on the type of securities in which it may invest, but the Asian Bond Fund will be limited to sovereign and quasi-sovereign bonds. If another crisis occurs, foreign reserves may have to be sold to help stabilise the currency, then the monetary policy has to sell Asian bonds, aggravating the crisis by depressing the bondmarket. This kind of procyclicality is something to be avoided in institutional design. The Asian Bond Corporation proposal does not have such a deficiency.

Table 3.7 shows a typical balance sheet of the Asian Bond Corporation. Here, the two currency examples are chosen for their simplicity. Suppose that the Asian Bond Corporation purchases 1 billion yen of Japanese government bonds and 200 million baht of Thai government bonds. Suppose that the initial exchange rates are 100 yen/US $\$$ and 40 baht/US\$. The total value of assets is US\$15 million or 1.5 billion yen. Suppose that the Asian Bond Corporation issues 15 units of bonds, then one unit will be initially traded at US $\$ 1$ million or 100 million yen.

Then, suppose that exchange rates fluctuate. Table 3.8 summarises possible cases of exchange rate fluctuations. In Case 1, both the yen and the baht depreciate against the US dollar, by the same percentage. The yen value of the $\mathrm{ABC}$ bonds does not change. In Case 2, both the yen and the baht depreciate against the US dollar, by 20 per cent. Again, the value of the ABC bonds in the yen does not change, although the value in terms of the US dollar appreciates. These two cases illustrate the point that is when Asian currencies move together with the yen, the exchange risk for Japanese investors is minimal.

Cases 3 and 4 illustrate situations where the yen and the baht move in different directions. In Case 3 , the yen depreciates, while the baht appreciates.

Table 3.7 Balance sheet of the Asian Bond Corporation (two-currency example)

Liabilities

$A B C$ sovereign bonds (15 units)
Assets

Japanese government bond

( 1 bilion yen)

Thai government bond

(200 million baht) 
Table 3.8 Fluctuations of $\mathrm{ABC}$ bond values

Yen/US\$ Baht/US\$ $\begin{gathered}\text { Unit price of } A B C \\ \text { bond (US\$ million) }\end{gathered} \begin{gathered}\text { Unit price of } A B C \\ \text { bond (yen million) }\end{gathered}$

\begin{tabular}{|c|c|c|c|c|}
\hline \multicolumn{5}{|c|}{ Initial exchange } \\
\hline rates & 100 & 40 & 1.00 & 100.00 \\
\hline Case 1 & 125 & 50 & 0.80 & 100.00 \\
\hline Case 2 & 80 & 32 & 1.25 & 100.00 \\
\hline Case 3 & 125 & 32 & 0.95 & 118.75 \\
\hline Case 4 & 80 & 50 & 1.10 & 88.00 \\
\hline
\end{tabular}

Note: 15 units of Asian bond corporation bonds with underlying assets of 1 billion yen and 200 million baht.

The appreciation of the baht against the dollar and the yen will push up the value of the $A B C$ bonds in terms of the yen. When the baht depreciates against the dollar and the yen, the value of $A B C$ bonds in terms of the yen will decline.

With these characteristics, would Asian bonds be attractive to Japanese investors? So long as the Asian currencies move in tandem with the yen (or the Singaporean dollar), the $A B C$ bonds will be attractive to Japanese (or Singaporean, respectively) investors. The coupon yields of underlying assets are denominated in local currencies, so that the coupon yield of $A B C$ bonds will be a basket value of underlying assets.

Let us examine the possibilities of Asian corporate bonds. $A B C$ corporate bonds can be issued just like government bonds. The Asian Bond Corporation should purchase corporate bonds that belong to the same risk categories (or credit rating) and have similar maturity and coupon payments structures. Corporate bonds should attract a wide class of investors since they carry higher risk and returns.

In the case of default (or non-payment) of bonds, legal procedures may be different from a country to another. This may be a substantial problem for investors wanting to invest in low-grade bonds. In some Latin American countries and Russia, government bonds were virtually defaulted. Corporate bonds are defaulted even in industrial economies.

Sovereign bond defaults pose particular difficulties, since they tend to result in a prolonged resolution process that may be marred by litigation against the country by minority bondholders. If changing terms and conditions is easier, say by a decision of super-majority (say 75 per cent), 
then a resolution process may be relatively easy. However, if changing terms and conditions require a unanimous consensus that may take a long time. Precisely this point led to the discussion of collective action clauses in the aftermath of the Mexican crisis of 1994-95 and the Brazil and Argentine crises from 1999 to 2002 (see Krueger 2001, 2002 for a proposal from the International Monetary Fund).

\section{The Asian Bond Corporation: pros and cons}

$\mathrm{ABC}$ bonds have the desirable feature of diversifying risk at the same time as offering reasonable returns. Investors in the low interest-rate economy will be attracted to the high-coupon rates of $\mathrm{ABC}$ bonds, if the currency risk is reasonable. Credit risk will be properly diversified, and informational asymmetry will be dealt with, since the Asian Bond Corporation will purchase bonds with similar credit ratings and provide information to investors.

\section{Why not global?}

One may wonder why investors are assumed to be regional, instead of global, in the Asian bond proposals. If bonds are issued internationally in New York or London, then the investor base is much wider, and the cost may be lower. This is a valid argument. If the government and corporations are reputable and highly rated so that they can issue local-currency denominated, international bonds with low premiums, then they should do so. However, not all Asian governments and corporations are held in such high regard. The view that the benefits of regional investment outweigh international investment is based on at least one of two related assumptions. Western or international credit-rating agencies and investors discriminate against Asian firms, for example, due to their credit rating being unfairly worse for Asian issuers compared to Latin American and central European firms. As well, investors in the region show more willingness to buy the bonds rather than international investors ('regional bias').

Asian investors are more interested in papers denominated in regional currencies than are international investors (known as 'home bias'). McCauley (2002) shows that about 46 per cent of 71 bonds issued by Asian institutions between April 1999 and August 2002 were bought by Asian investors in the primary market offering. Investors' familiarity with issues and correlations among the regional currencies are the basis of regional bias. For bonds denominated in local currencies issued by familiar regional brand names, regional investors will demand less premium than global investors. 
A further point is that business hours overlap in the Asian region. Once an efficient trading and settlement system is developed, regional investors can enjoy real-time settlement in their business hours. This will be an additional benefit for investors in regional bonds.

\section{Role of government}

\section{Lack of market infrastructure}

Since the Asian region has fragmented financial markets, there is little common market infrastructure. The trading system is not coordinated between Tokyo, Hong Kong SAR and Singapore. Clearing and settlement may take time, since a common depository is not available. Bankruptcy codes are different from one country to another, so that investors are not quite sure what would happen should either default or bankruptcy occur. Protection of minority bondholders may not be a common practice. Standardised credit rating for regional companies is not available, as credit rating companies in the region offer only domestic credit ratings.

An Asian bond proposal should include plans to improve market infrastructure, without which any promotion of Asian bonds will find a severe constraint sooner or later.

In terms of providing market infrastructure and legal harmonisation, the role of the government cannot be overemphasised. Cooperation among the governments in the region is essential to the success of regional bondmarkets.

\section{Government versus market}

Some critics think that government's role should be confined to establishing legal and market infrastructure, while others regard it desirable and important that governments in the region cooperate in promoting Asian bonds by issuing benchmark bonds, harmonising regulation and taxation.

Unless foreign investors are active, the government will have less incentive to reform markets. Unless issuers are abundant, investors will not have the incentive to research, and voice what they see as obstacles. There could be a bad equilibrium (no investors because of no issuers; and no issuers because of no investors) and a good equilibrium (a deep region-wide market). Cooperation amongst the governments, as well as cooperation between the government and the investors, is needed to jump from the bad equilibrium to the good equilibrium. A government-led strategy is needed to improve coordination among investors and issuers.

In fact, pushing the agenda will hasten necessary reform in domestic markets. The current lack of market infrastructure suggests that potential 
benefits from reform and cooperation among regional governments are considerable.

\section{Attractiveness to investors}

Some market participants and economists question the attractiveness of $A B C$ bonds.

Investors want to make decisions themselves on the basis of weights. $A B C$ bonds are essentially mutual funds, or currency boards, in the sense that the values of $\mathrm{ABC}$ bonds are matched by the sum of underlying asset values. However, unlike mutual funds, assets in the basket are fixed in the beginning and not managed actively. Even international investors, who want to diversify risk by holding various currencies and various class of risk, would prefer to manage their own portfolio rather than maintaining a fixed-weight portfolio as the regional financial environment changes.

This criticism can be rebutted as follows, although there is some truth in the argument. The critics assume that investors hold only $\mathrm{ABC}$ bonds. In the real world, sophisticated investors hold many kinds of assets and $A B C$ bonds will be only one of the alternatives. Investors will also adjust their portfolio according to their perceived business prospects. Investors will increase or decrease the ratio of $A B C$ bonds relative to other regional or international currencies, so this point cannot be a criticism of holding $A B C$ bonds. The issue will then be the benefits and costs of having a pre-packaged basket. Having pre-packaged assets (similar to the role of having derivatives) saves transaction costs. For example, suppose that investors would like their portfolio to weigh heavily on the Thai baht, relative to other currencies in the basket. Investors would buy the baht bond, and sell all other currencies (say Korean won, Japanese yen, Malaysian ringitt, Singaporean dollar and Indonesian rupiah). Buying additional baht bonds while selling the $A B C$ bonds would mimic this operation. Conversely, the investor may like to shed a particular currency or a particular bond from the portfolio that originally contain $\mathrm{ABC}$ bonds. The investor does not have to sell all $\mathrm{ABC}$ bonds to get rid of the weak currency from the portfolio. The investor can simply sell forward the amount of the weak currency (bond) equivalent to the value in the component of the $\mathrm{ABC}$ bonds, while maintaining the $\mathrm{ABC}$ bonds in the portfolio.

So, the attractiveness of $\mathrm{ABC}$ bonds as a diversified basket product should rest on the savings to be made on the transaction costs of buying and selling the individual bonds together, just like a derivative. Given that domestic markets are not yet fully open to foreign investors and steady 
supplies of government bonds are not available, such costs would be very high.

Does the high correlation among the currencies provide more or less of a reason to promote the $\mathrm{ABC}$ bond? The regional currencies now show higher correlations among themselves than before. It was also the case, during the currency crisis of 1997-98, that the contagion effect made all currencies in the region decline simultaneously.

One view is that high correlation of the currencies in the region makes the $A B C$ bonds less attractive, in the sense that it reduces the benefits of diversification. When investors seek a fully diversified portfolio, they should try to find financial assets that have negative correlation with most of their original assets, without compromising average returns. But this may not be possible in the real world. We do not find too much diversity in the portfolios of major institutions, and even less among small investors.

Another view is that high correlation of the currencies in the region makes $\mathrm{ABC}$ bonds more attractive, in the sense that those who are worried about currency risk may find the high correlation attractive, for example, riskaverse investors who exhibit home bias. $\mathrm{ABC}$ bonds may be quite attractive to these investors as the regional currencies move together.

The critics might ask whether these investors would be more attracted to a single-currency high coupon-rate foreign bond of a country with high correlation to the home currency. But suppose that the Korean won, the Thai baht and the Singaporean dollar have roughly the same correlation coefficient with the Japanese yen, then the diversification argument for these currencies still works. So, the high correlation of regional currencies is a plus for the Japanese investors when compared to other bonds, like the Canadian dollar or Australian dollar, while among the Asian currencies, with similar correlation coefficients, having a basket currency is better than the single currency. Another benefit of the $A B C$ bond over a single-currency foreign bond is the diversification of credit risk.

\section{Secondary market of $\mathrm{ABC}$ bonds}

Since the value of $A B C$ bonds will float against all currencies, the value will fluctuate against any of the regional currencies. When it is traded in Tokyo, the value will be quoted in the yen, and when it is traded in Hong Kong SAR, it may be quoted in the Hong Kong dollar or the US dollar. It all depends on the market facility and investors' preference. 


\section{Valuation of $A B C$ bonds}

The valuation of an $A B C$ bond may or may not be a simple matter. Critics think that valuation would become so difficult that financial engineering techniques will be required to calculate the theoretical value.

However, the valuation would be straightfoward if the domestic markets for all underlying bonds in the asset side are deep and efficient. Then the value of the $A B C$ bond is simply calculated in real time as the weighted sum of the underlying bonds. Any premium or discount that $\mathrm{ABC}$ bonds may show is the positive or negative value of pre-packaging them.

The valuation of an $\mathrm{ABC}$ bond may be difficult if domestic markets are not deep and efficient. In that case, the difficulty comes from calculating the potential market value of bonds with currency risk, interest rate risk and credit risk. However, this is a problem also affecting an individual bondmarket without sufficient liquidity. It would not neccessarily be the case that the difficulty in valuation would turn off institutional investors.

\section{ABS Asian bonds}

Some Asian bond proposals, in particular those from Korea, include securitisation of various kinds of assets. Asset-backed securities (ABS) can be issued for international investors. If distressed assets are to be securitised, it is proposed to separate senior debts and junior (subordinated) debts, and only senior debts are supposed to be marketed internationally. This is an application of a scheme that the Korean financial institutions are doing domestically (see Oh et al. 2003).

Critics point out that, first, distinguishing between senior and subordinated debts may be difficult. They are especially problematic if assetbacked securities bonds are marketed internationally in different countries, reflecting the difference in bankruptcy laws and implementation of asset collection. Therefore asset-backed securities bonds from different countries may not be packaged into a basket bonds, unless separation of senior and subordinated bonds is harmonised by regulation and the credit rating agencies.

\section{Credit enhancement}

In the immediate future, the number of potential issuers of Asian bonds may not be many, due to low credit rating. If a default probability perceived by investors deviates from a rationally calculated default probability of bond issuers, due to unfamiliarity or risk averseness, then there may be a role for the government or international institutions to enhance credit rating by 
provision of public money. Once familiarity is gained and history shows a better-than-expected survival rate, public support may be withdrawn. Such credit enhancement could be provided by the Japan Bank for International Cooperation or the Asian Development Bank.

Credit enhancement should not be a 100 per cent credit guarantee, rather, starting 50-80 per cent, with pre-announced schedule of declining ratio to 0 per cent within ten years. This will avoid the problem of moral hazard on the part of issuers, and will assure confidence on the part of investors.

\section{Investor base}

One may also question a list of potential investors. Bond investors are known to be risk averse, and Japanese investors particularly so, especially after the default of Argentinean Samurai bonds. However, Japanese investors' appetite for Samurai bonds issued by Bulgaria and Greece, in addition to Argentina, in the past show that they can take risk. Australian and Canadian bonds are also selling well, mainly due to high coupon yields. The spread of 4-5 per cent seems to compensate for exchange rate risk.

Singaporean and Malaysian pension funds (provident funds) may be other large potential investors in the region. They have an informational advantage on companies in the Southeast Asian countries, and may be willing to take risk for reasonable long-term returns.

\section{Concluding remarks}

An Asian bondmarket has the potential to become a major capital market in the region, providing that Asian governments realise the importance and cooperate in improving market infrastructure.

In order to provide better information and diversified risk, Asian basket currency government bonds can be constructed as bonds backed by a mix of local currency government bonds. The value of $A B C$ government bonds is a weighted average of the values of underlying assets. When exchange rates fluctuate, the value of $A B C$ bonds fluctuates as a weighted average of underlying assets. The coupon yield of $A B C$ bonds is also a weighted average of underlying bonds.

Once the benchmark government bonds are created, $A B C$ corporate bonds can be issued in $A B C$ currency units. This provides an alternative channel of fundraising for Asian corporations. This provides high yield, reasonablerisk investment products for investors in the region.

Governments can help to develop such a market by providing credit enhancement in the early stages, and provide a suitable financial 
infrastructure. The governments of the region, especially Japan, Korea, Thailand and other willing Asian countries, are urged to cooperate in setting up the Asian Bond Corporation and promoting development of the Asian bondmarket so that the region can reduce reliance on the banking system, and help directly channelling saving in the region into borrowers in the region. The $A B C$ sovereign bond may be created without significant changes to the current infrastructure; it is up to the will of the fiscal authorities. Securities firms will find investors who are willing to invest in a basket of local currency bonds with different coupons. The healthy development of capital market in the region will be important for the region in order to avoid another financial crisis in the future.

\section{Note}

1 See http://www.boj.or.jp/en/about/03/un0306a.htm for the announcement. 